three distinct types, each being represented by forms which have attained the Dalliniform loop-stage of Beecher, viz. Coptothyris, Macandrevia, and Dallina. These three genera are also characterized by distinct types of beak characters, dental plates, etc. Thus three evolutionary stocks can be clearly recognized, in each of which Dalliniform loops have been attained by parallel evolution. There appear to be other stocks present, but in these there is as yet no evidence for the separate attainment of the Dalliniform loop.

The study of the hinge characters of the species of Dallininæ contained in my collection (comprising most of the known forms) has revealed many interesting features which have an important bearing upon the classification of both recent and fossil forms. For some of these forms it will be necessary to create new genera.

Manchester Múseum.

J. WILFRID JACKSON.

September 4, 1918.

\title{
THE CANINIA-SEMINULA HORIZON OF PRODUCTUS HUMEROSUS.
}

SIR, - I have just received my copy of the Q.J.G.S., containing Mr. Parsons' most excellent paper " On the Carboniferous Limestone of the Leicester Coalfield". I want to ask him to reconsider the question of the horizon of the beds containing Productus humerosus (P. sublevis). Following Professor Sibly, who referred the Cauldon Low (Staffs) Limestones to $D_{1}$, he has not pointed out that $P$. humerosus is an important zonal fossil both in Belgium and the Clitheroe area, indicating a Caninia-Seminula horizon. Therefore, one must pause to think before beds containing it are assigned to a much higher zone. The palæontological evidence of the Cauldon Low beds is strengthened by the presence in them of other members of the $C-S_{1}$ fauna. Papillionaceous Chonetes, Bellerophon cornuarietis, and other members of that genus, and several large Gasteropods which can be matched in Belgium and Clitheroe. I note that Cyrtina septosa occurs with $P$. humerosus. This, too, indicates the lower zone.

Then, again, the barrenness of the beds and the absence of Lithostrotion and a Dibunophyllum fauna are rery noteworthy. I have, no doubt, in my own mind that the Cauldon Low beds are of Caninia age, and the whole question will be more fully discussed in a forthcoming paper on the Clitheroe area.

ON SERvice.

WheELTon Hind, M.D., B.S., F.R.C.S.

September 7, 1918.

STRATIGRAPHICAL POSITION OF THE CORALLINE CRAG.

ERratuM. - In Mr. F. W. Harmer's article in the September Number, "Stratigraphical Position of the Coralline Crag," p. 410, for Walton horizon read Oakley horizon= Poederlien, and for Oakley horizon read Walton horizon $=$ Scaldisien - the names Walton and Oakley having been reversed. 